-

\title{
Design Of Property Sales Information System PT.Quality Property Indonesia
}

\author{
Ferry Sudarto ${ }^{1}$, Mulyati ${ }^{2}$, Eka Purnama Harahap ${ }^{3}$, Fira Arbaimaniar Nurul ${ }^{3}$ \\ ${ }^{1,2,3}$ Raharja University, Jl. Jendral Sudirman No.40 Modern Cikokol Tangerang \\ e-mail: ferry.sudarto@raharja.info, mulyati@raharja.info, ekapurnamaharahap@raharja.info, \\ fira@raharja.info
}

To cite this document:

Sudarto, F., Mulyati, Harahap, E. P., \& Nurul, F. A. (2020). Design Of PropertySales Information

System PT.Quality Property Indonesia. Aptisi Transactions on Management (ATM), 4(2), 150-157.

DOI:

https://doi.org/10.33050/atm.v4i2.1272

\begin{abstract}
In the property business, this company can help provide a place for long-term business and investment. In this discussion the property sales system used is to use SWOT, so that it can help stakeholders in make decisions. In this case the author uses several methods including research methods, analysis methods, design methods, testing methods. Where the research methods in the form of observation, interviews, literature studies. The analysis method which uses SWOT analysis. The design method uses a design model using UML (Unified modeling language), PHP a database using MYSQL, and browser using Google Chrome. The testing method uses a blackbox. In this case the researchers have several objectives in conducting research in this thesis including To facilitate marketing to market property products sold by entering the list of properties to be sold, To help the process of buying and selling transactions quickly, precisely, and safely, To help process sales reports. Then the results customer will easily find the property to be purchased, Easing the burden on admin staff in the process of buying and selling property, Can speed up sales reports and can reduce errors in recording reports.
\end{abstract}

Keywords: Sales, SWOT (strengths, weaknesses, opportunities, threats), MYSQL.

\section{Introduction}

Property business is a type of business that is directly or indirectly related to the interests of many people. The community needs property products, especially housing to meet their basic needs. In the property business it can also help provide a place for business and long-term investment. In a company in general and more specifically in the property development business, Marketing plays an important role for conducting integrated communication aimed at providing information from the company to consumers about property goods offered. This is where it becomes important that there is a link between producers on the one hand and consumers on the other hand in order to bridge the information, so the role of marketing as information media becomes very important. This information media becomes important in order to achieve the objectives to meet the needs and desires of consumers. 
The development of information technology also penetrated into the sales business sector, as well as property at PT. Quality Property Indonesia. The company is engaged in property by selling its products in the form of houses, apartments and shop houses, which began in 2015 until now. In handling its sales information system this company can be said to still do it manually. The company is still using the conventional sales system in the form of marketing through word of mouth and using media brochures, so that the scope of marketing sales is still limited and can not be extended to various areas causing the products sold are less well known by the wider community. Another obstacle experienced by property sales service companies is the difficulty in buying and selling transactions, namely storing and searching for buyers and sellers' data that are piled up in the file cabinet, the difficulty of recording reports on property unit sales still using Microsoft Excel, and in making reports still using Microsoft Excel.

By looking at the problems mentioned above, there needs to be a study of these conditions. By providing an online sales information system or using a website, it is expected that the entire sales system at PT. Quality Properti Indonesia can provide services and information easily, quickly, accurately for customers, while also being able to help process client data reports, home unit data, and sales reports. Based on this background, the authors take the title "DESIGN OF PROPERTY SALES INFORMATION SYSTEM AT PT. INDONESIA QUALITY PROPERTY ".

\section{Research Method}

Basically every scientific work has a basis in data retrieval, as well as in this study using 4 methods to retrieve data and research a problem, namely data collection methods, analysis methods, design methods and black box testing.

\subsection{Method of collecting data}

\section{a. Method Observation}

Is a method of collecting data through direct observation or careful and direct observation in the field or research location.

This research was conducted for 3 (three) months from the beginning of October to December 2019 at PT. Quality Property Indonesia, which became the location of the study in order to obtain data and information relating to the type of research. The data that the researchers took were the profile of PT. Quality Property Indonesia, and the structure of PT. Quality Property Indonesia, and the task of PT. Quality Property Indonesia.

b. Method Interview

In this method the author conducted a question and answer process to Mrs. Fifi as the Principal of PT. Quality Indonesia Property by wanting to create a Property sales system that aims to facilitate the marketing of property, facilitate buying and selling transactions, and facilitate in making reports.

From the interview with Mrs. Fifi, it can be concluded that the system implemented at PT. Quality Properti Indonesia is currently marketing the property on brochure media and through word of mouth, the transaction process is still manual with the example when the customer has already paid by making a written receipt, and customer data is still stored neatly on the shelf it will be difficult to search for and long, and recording reports still use Microsoft Excel.

\section{c. Literature Review}

All efforts are made to obtain and collect all written information that is relevant to the problem under study [1]. This information was obtained from books, research reports, regulations, regulations and other sources.

1. Research conducted by Herry Mulyono, 2017. Analysis and design of Web-Based Plywood Sales and Order Information Systems at PT. Kumpeh Karya Lestari Jambi. This research designs and builds information systems for selling plywood raw materials online using database for document storage, stock usage and sales, In research, researchers create a system that is integrated with databases including systems that can help document each transaction as well inventory, sales function [2].

2. Research conducted by Prasetyo, 2014. Design of Information System for Product Packaging Product Sales at CV Ismie Jaya. This research designed a 
sales information system using database with the existence of this new system the data is more accurate, data cannot be lost, makes it easy for sales reports and to facilitate decision making [3].

3. Research conducted by Andri Prasetyo, 2016. Web-Based Sales Information System at PT. Cahaya Sejahtera Sentosa Blitar. This research designs a webbased sales information system for sales reports In the study, researchers used the CSS program to support a web-based sales system[4].

4. Research conducted by Rice Novita, 2015. E-Commerce Based Fertilizer Sales Information System at PT. Pertani (Persero) Riau branch. This research produces a Web-based sales information system to facilitate data storage on the web, and for sales reports. In research, researchers create a system that is integrated with databases including systems that can help document each transaction as well inventory, sales function [5].

5. Research conducted by Qi Zhang, 2017. Car Sales Analysis Based On the Application of Big Data In the results of this study argue that each type of car brand has a different sales results. The method used in this research is quantitative method[6].

\section{d. Method Analysis}

In the analysis method the author analyzes an existing system, using the SWOT (Strengths Weeknesses Opurtunities Threats) method. SWOT analysis is a method used to look at the condition of agencies, both internal and external which are then used as indicators to determine the strengths, weaknesses, opportunities and threats to the agency, so that it can help stakeholders in making decisions [7].

\section{e. Method Testing}

In the process of testing online shopping websites at PT. Quality Property Indonesia, researchers use the Blackbox Testing method, which is a trial method that focuses on the functional objectives of the software. Blackbox testing method is used to find errors in several categories, including functions that are wrong or missing, display errors, output errors, errors in data structures or external database access and performance errors [8].

\section{Results and Analysis}

PT.Quality Property Indonesia is a company engaged in Real Estate business activities in the form of property such as houses, apartments and shop houses. PT. Quality Property Indonesia was established on August 8, 2015 and the company is located at Ruko Crystal 1 No.22 Jl. Gading Golf Boulevard, Gading Serpong, Tangerang.

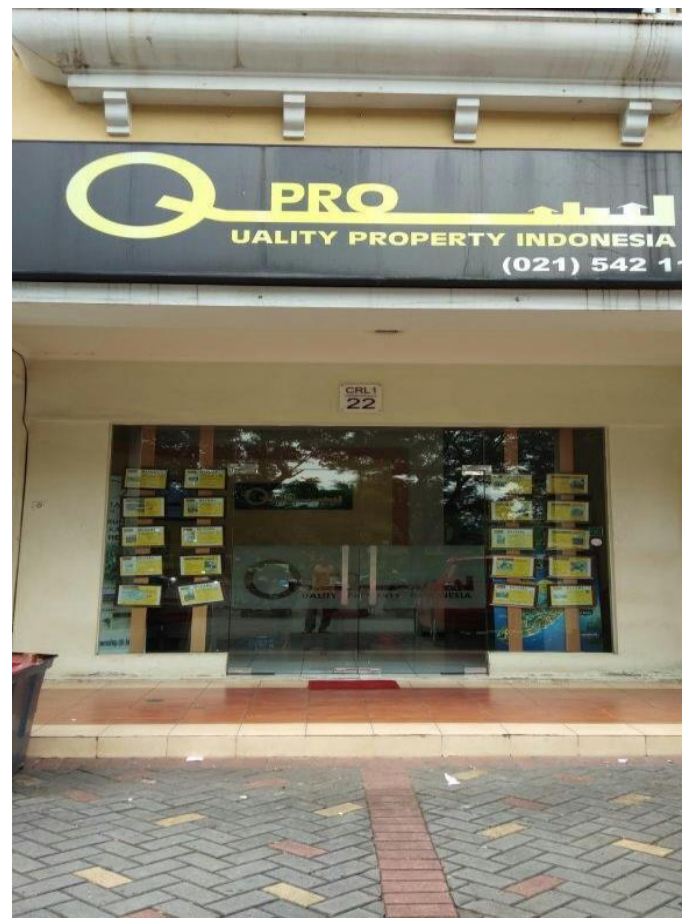


Figure 3.1. PT. Quality Property

Based on the analysis of the proposed system it is known that the current system is still manual so that it does not meet the needs in processing data efficiently and effectively. From this analysis it is known that the next step is to design a property sales system that aims to meet customer needs in making purchases of property units and facilitate the company's performance efficiently and effectively.

To design systems and system procedures proposed by researchers, use the UML (Unified Modeling Language) model using Visual Pradigm software, where this software is able to design procedures that are useful for visualizing the design of the system to be built later.

In the design process of the property sale will be described using Use Case Diagrams, Activity Diagrams, Squence Diagrams, and Class Diagrams.

Explanation of the proposed system diagram in the property sales transaction process is described using the Use Case Diagram in the following figure:

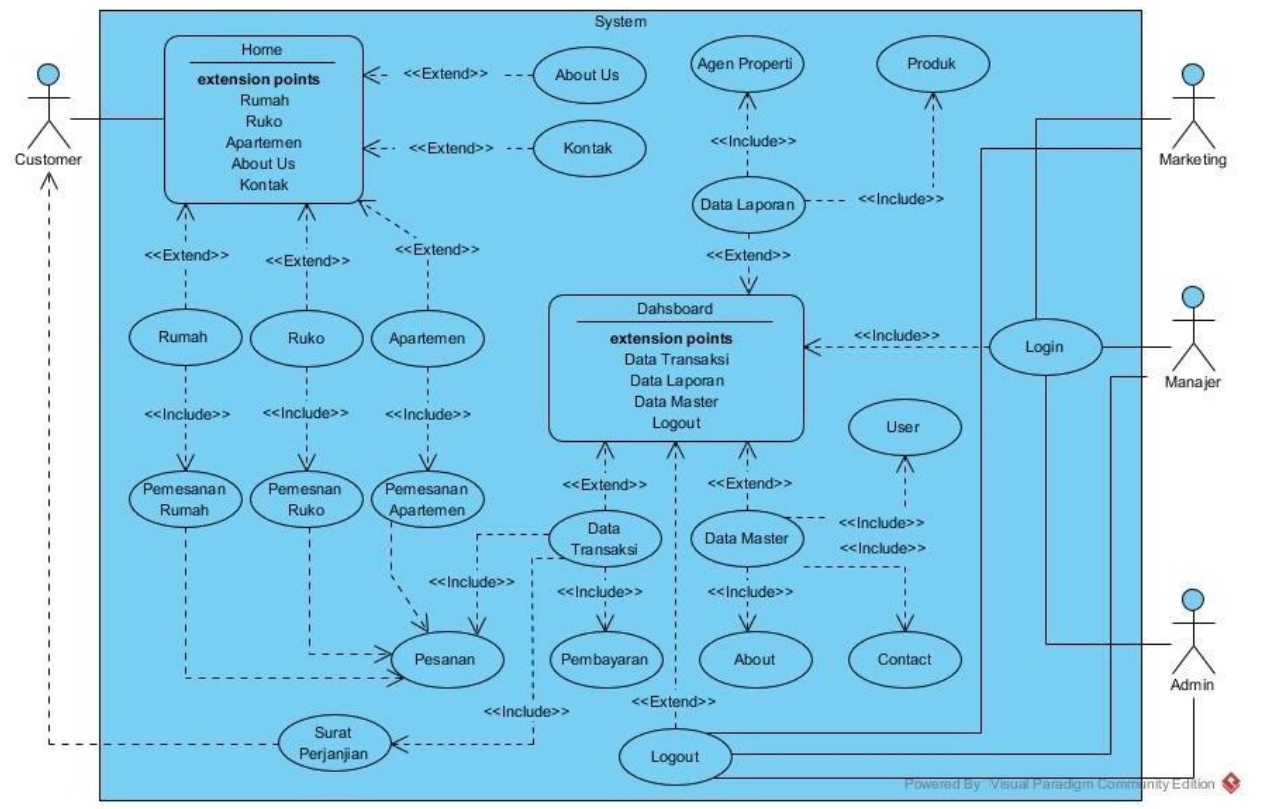

Figure 3.2. Use Case Proposed Diagram

Based on Figure 4.1 Use Case Diagram of the proposed system there are:

- 1 (one) system that covers activities in the property purchase transaction process.

- 1 (one) actor who carries out activities as an administrator.

- 3 (three) actors who carry out activities as users.

- 7 (seven) use cases conducted by customers that have 3 (three) extend and 3 (three) include.

- 14 (fourteen) use cases conducted by the user, that is, admin enters home data, submits sales report, print customer data, print receipts, print purchase agreement, 

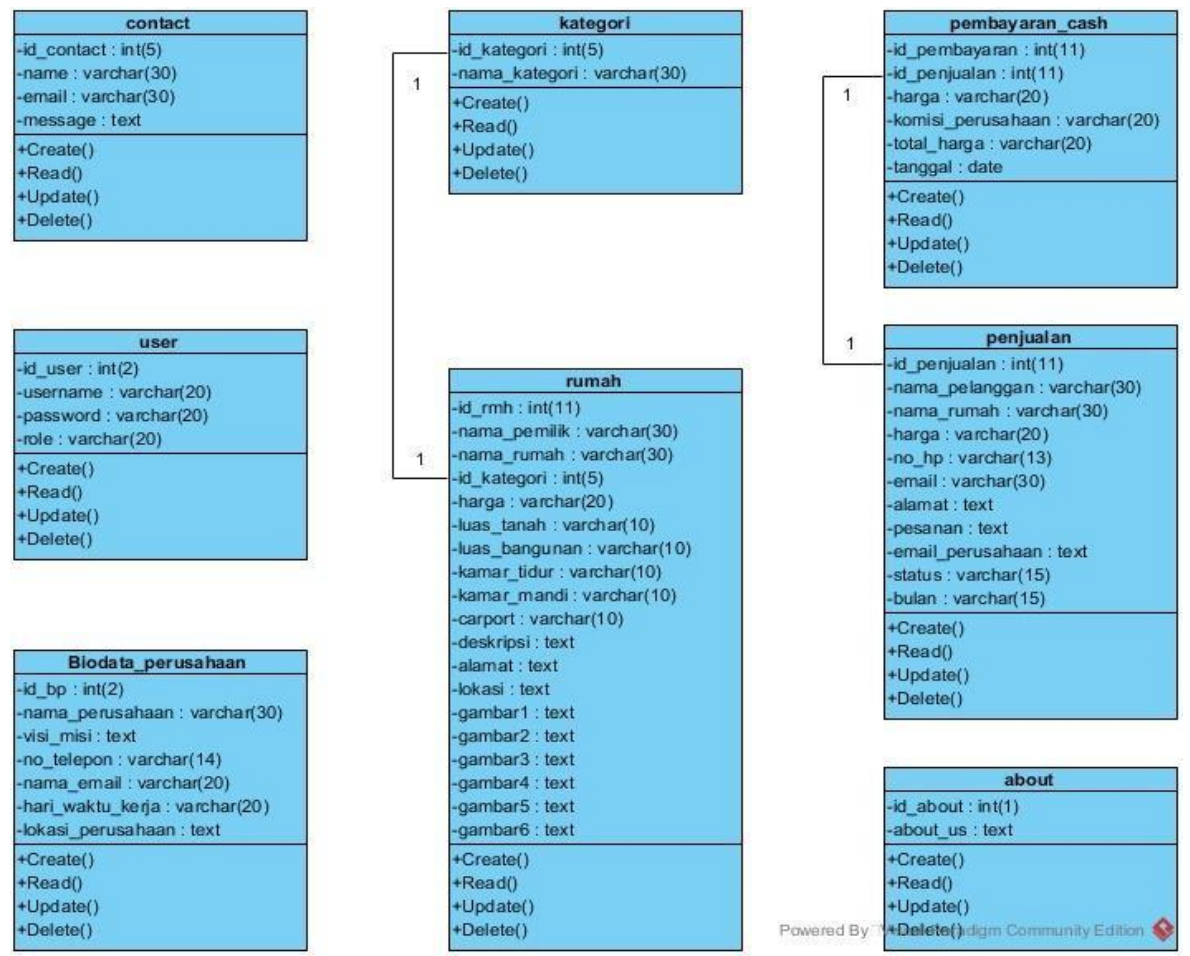

Figure 3.3. Third Normal Form (3NF)

The normal form of a database relationship design is done by using several stages

\subsection{System View Customer}

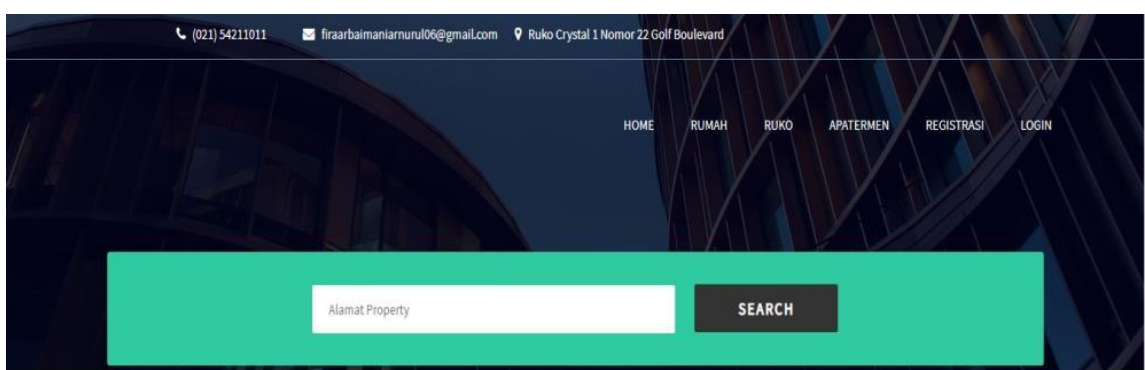

RUMAH

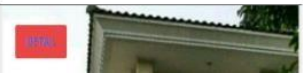

Figure 3.4. System View Customer

The first interface page on access by prospective customers by typing the web address. Displays a product order form when a potential buyer clicks the buy button along with the product details that you want to order.

\subsection{System View Login User}




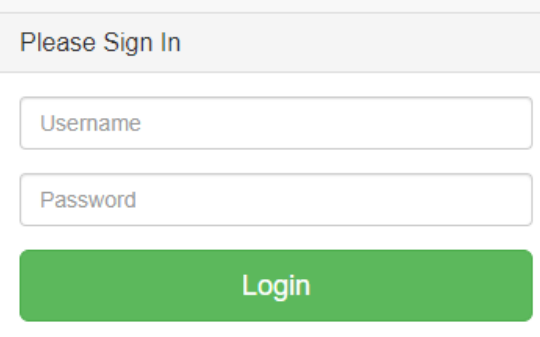

Figure 3.5. Login User

As the security of the system when the user will use the system.

\subsection{Dashboard User}

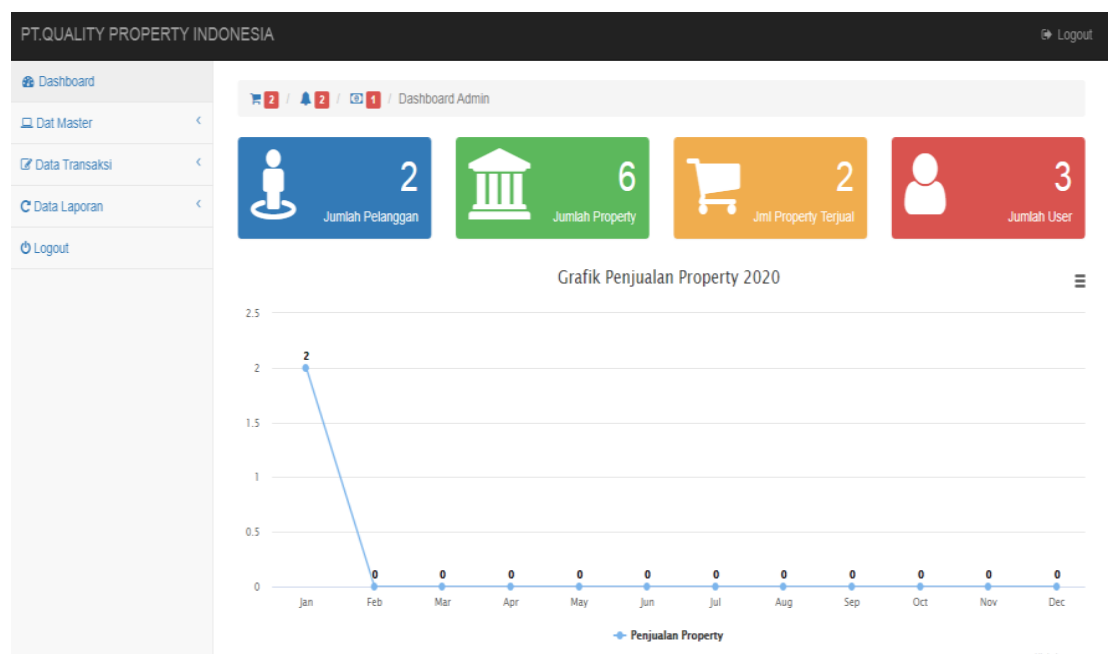

Figure 3.6. Dashboard User

Interface page when first time time the user logs into the system

\subsection{System View Sales}




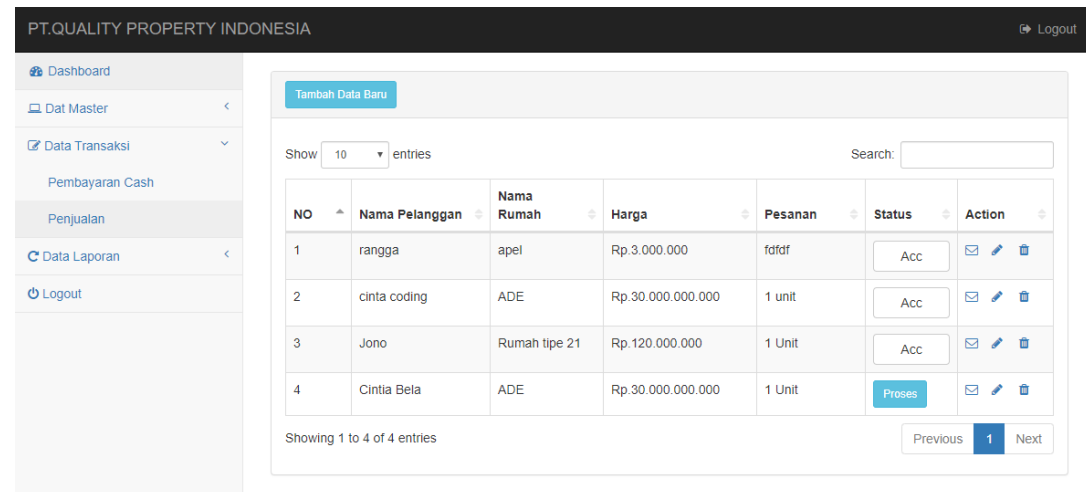

Figure 3.7. System View Sales

Display of incoming sales systems, the results of input made by customer.

\subsection{System View Payment}

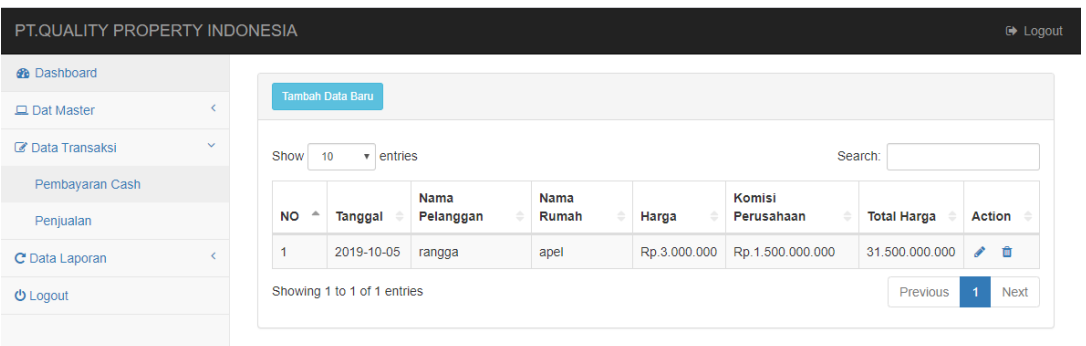

Figure 3.8. system View Payment

Data from customers who have made payments containing the date of payment and details of nominal money has been paid.

\section{Conclusion}

Based on research that has been done using several research methods, in terms of problem formulation, and objectives and benefits, it can be concluded several things regarding the analysis of PT.Quality Property Indonesia's management information system. Property sales system at PT.Quality Property at this time the customer comes to the office to consult with marketing to explain the product you want to buy after that when it is fixed to buy the customer submits data such as ID card / NPWP then make payment of the sign so after that the customer submits proof of payment to marketing and marketing submit to the admin staff to check, if it is entered the admin staff issued a receipt is still made in writing and submitted to marketing and marketing is handed back to the customer. Then the admin staff makes an agreement letter to be signed by the seller and buyer, if the admin staff has signed a copy of the letter to input sales reports using Microsoft Excel manually then submit it to the accounting staff. 
So to optimize the sales system PT.Quality Property Indonesia needs to take several steps such as: marketing, the system (website) online sales process to facilitate customers, marketing and admin staff in accessing all information. By using a system analysis used is a design method using UML (Unified Modeling Language), and testing methods using the Black Box method, for programming languages using PHP (Hypertext Preprocessor), MySQL database for making applications, with XAMPP connections to produce the system.

\section{References}

[1] Aini, Q., Anoesyirwan., \& Yuliana. (2019). Effect Of Cloud Accounting As Income Statement On Accountant Performance. Aptisi Transactions On Management (ATM), 4(1), 13-21.

[2] Deti, L. K., \& Mulyono, H. (2017). Analisis Dan Perancangan Sistem Informasi Penjualan Dan Pemesanan Plywood Berbasiskan Web Pada PT. Kumpeh Karya Lestari Jambi. Jurnal Manajemen Sistem Informasi, 2(1), 303-317.

[3] Sitanggan, Bismar dkk.2014. Pengaruh Penerapan Prinsip-Prinsip Dasar Good Corporate Governance Terhadap Tingkat Kepuasan Vendor Pada Proses Pengadaan Barang /Jasa Di PT Indonesia Power Kantor Pusat.Jakarta Selatan: Jurnal Penelitian Dan Pengembangan Humanior A Vol 11 No 2.

[4] Prasetyo, A., \& Susanti, R. (2016). Sistem Informasi Penjualan Berbasis Web Pada PT. Cahaya Sejahtera Sentosa Blitar. Jurnal IImiah Teknologi Informasi Asia, 10(2), 1-16.

[5] Novita, R., \& Sari, N. (2015). Sistem Informasi Penjualan Pupuk Berbasis E-Commerce. Jurnal Teknoif, 3(2).

[6] Zhang, Q., Zhan, H., \& Yu, J. (2017). Car Sales Analysis Based On the Application of Big Data. Procedia Computer Science, 107(C), 436-441.

[7] Rahardja, U., Moein, A., \& Lutfiani, N. (2018). Leadership, Competency, Working Motivation and Performance of High Private Education Lecturer with Institution Accreditation B: Area Kopertis IV Banten Province. Man India, 97(24), 179-192.

[8] Rahardja, U., Harahap, E. P., \& Dewi, S. R. (2019). The Strategy of Enhancing Article Citation and H-Index on SINTA to Improve Tertiary Reputation. TELKOMNIKA, 17(2), 683-692. 